\title{
Interview
}

\section{Mother language teaching in Portugal. An interview with João Costa and Isabel Margarida Duarte}

\author{
Isabel Sebastião \\ Centre of Linguistics of the University of Porto
}

(Text received July 25 2019; accepted July 25 2019)

DOI: https://doi.org/10.5565/rev/jt13.813

João Costa is a Linguistics Professor at the Faculty of Social and Human Sciences of the Universidade Nova de Lisboa. He has a degree in Linguistics from the Faculty of Arts and Humanities of the Universidade de Lisboa (1994), and a PhD in Linguistics from the University of Leiden - The Netherlands (1998), with part of his work developed at the Massachusetts Institute of Technology (MIT). In 1998, he received the Research Award from the Portuguese Association of Linguistics. Until November 2015, he was Dean of the Faculty of Social and Human Sciences at the Universidade Nova de Lisboa and president of the Scientific Council of Social Sciences and Humanities. He was a member of the Scientific Council of the National Reading Plan, the National Commission of the International Institute of the Portuguese Language and the Consultative Council of the Camões Institute. He is currently Secretary of State for Education in Portugal.

His research areas of interest are Formal Linguistics, Acquisition and Development of Language and Educational Linguistics.

$\mathrm{He}$ is the author of several books and more than 100 articles and book chapters.

Isabel Margarida Duarte is an Associate Professor of Linguistics at the Faculty of Arts of the University of Porto and belongs to the Department of Portuguese Studies and Romance Studies. Graduated in Romance Philology (1977), she completed her master's degree in Teaching Portuguese Language (1990) and a $\mathrm{PhD}$ in Linguistics (2000), at the Faculty of Arts of the University of Porto. She is Vice-President of the Council of Representatives, Member of the Scientific Council and Erasmus Coordinator of the same institution. Under various protocols and invitations, she has taught at Universities in France, Romania, Italy, Spain, Germany, Norway, Sweden, Finland, Brazil, Cape Verde, Timor, South Africa, United States, Bulgaria, Hungary, The Czech Republic, Serbia, India, Vietnam, China, amongst other countries.

Her research areas are the Pragmatic Discourse Analysis; confrontation between Romance languages and Linguistics and Portuguese teaching.

Highlighted in her work, are publications related to speech reporting, discursive markers, forms of treatment, Portuguese teaching (Mother Language and Foreign Language). 


\section{Interview (June, 2019)}

I would like to thank Professor João Costa and Professor Isabel Margarida Duarte for taking their time and for the opportunity to exchange some ideas on a never-ending topic: language teaching in Portugal. In general, this interview intends to present mother tongue teaching in Portugal from the personal view of Professor Isabel Margarida Duarte, who has been working in this field for more than 30 years, and also from the perspective of Professor João Costa (State Secretary) who has contributed, in different plans of action, to continuous improvement in this area. It is intended not only to highlight characteristic features of the current state of mother tongue teaching, but also to understand a little more about the paths taken in the last twenty years and the prospects for its continuous improvement.

IS: Designing a curriculum requires basic decisions as to what should be learned, which will shape the specific learning of a given discipline. Curricular decisions in Portugal in recent years have undergone ideological changes. How do these changes reflect the path of language teaching and contribute to the development of mother tongue teaching?

IMD: Portuguese language teaching over the past 30 years has changed substantially, including the different ways in which it is understood. With regard to Basic Education, new syllabi introduced since 1991 have, undoubtedly, introduced valuable developments compared to previous ones, as learning has been based on listening, speaking, reading and writing skills. However, the then so-called "workings of the language" had been pushed to the bottom of the Syllabus agenda, a symbolic position it also held in its theoretical design and, as a result thereof, in teaching practices. This syllabus left more room than in the past for reading, even though the selected texts proposed gave preference to, in perhaps too exclusive a manner, the students' contact with contemporary texts. In 1997, the document $A$ língua materna na educação básica [Mother tongue in basic education] introduced significant improvements as far as the guidelines were concerned, for it emphasised the skills to be achieved in each area, per cycle and at the end of compulsory schooling. In 2009, providing the performance descriptors per area and skill was also one of the concerns in the syllabus that replaced the 1991 one. The syllabus disclosed in 2015 chose to eliminate the notion of skill and the expression "explicit knowledge of the language" (a term from 2009) was replaced with the word grammar. However, this area became more inconsistent. On the other hand, contact with literature, identified by the term "literary 
education", which is considered a field equivalent to reading, writing, understanding and oral expression and grammar, prevailed.

When it comes to Secondary Education, proposals have vacillated between syllabi focused on the literary text from all currents and periods (see, for example, the 2014 syllabus), and others in which key and indisputable works of Portuguese Literature have been selected and which every Portuguese person should be familiar with (in 2001/2002, for example). Similarly, there is practically no reference to grammar in the first proposals (such as the ones made in 2014), whereas in others it does appear in the curriculum design. There have been times when the syllabi were split into two groups (Humanities students - Portuguese A - and students in other fields - Portuguese B). At other times, such as today, in which the programmes distinguish between the Portuguese (language) syllabus and the Portuguese Literature syllabus, which is optional for students who are taking the scientific-humanistic course of languages and literature. The Portuguese syllabus, however, also contains an extensive list of mandatory texts, organised in chronological order.

In this back and forth process of different views as to what should be learned in Portuguese, some influenced by Literature and others by Linguistics, the fact is that today there is great concern about grammar issues, about contact with literature, and a greater concern with turning students into readers. We believe that it is more useful for the students' education to balance scientific benefits from Linguistics, Literature and Didactics, and for this reason, this harmonisation should be reflected in the guidelines.

A number of other documents connected to the syllabus (targets, support textbooks, profiles, etc.), designed to remedy any less successful aspects in the programmes in force are frequently added, so as not to constantly change the reference works with which teachers have to work. Let me add that there are heated discussions in the public and in the media about any changes made in the field of Portuguese language, giving it great visibility. In other words, changes need to be considered with a large amount of good sense, as each change crucially depends on the leaders' perceptions about education, more precisely about the teaching of Portuguese.

IS: On 1 August 2018 you wrote in Jornal Público, "A recent analysis of the national exam results over recent years shows that poor outcomes are not related to the memorisation of contents, but rather to contents that require applying knowledge in new situations, reasoning, analysis, interpretation and writing." Two official documents were recently published that serve as 
guidelines to the teaching-learning process within compulsory education: The Student Profile at the end of Compulsory Education and Essential Learning. In your opinion, to what extent do these documents give us a new perspective on how to deal with mother tongue teaching? Do they make room for a productive compromise between grammar and verbal skills (listening, speaking, reading and writing)?

JC: These two documents have one single motivation. To promote better and deeper learning. The Student Profile is the basis of our curriculum, a competence-based curriculum, listing areas of competence, principles and values to be developed in the 12 years of school. This includes language awareness, problem solving, communication, critical thinking, creativity, aesthetic and artistic sensitivity, among others. There is a practical implication: disciplinary contents must converge to the development of these areas, that is, the contents are not a goal by themselves, but a tool to promote knowledge and competence. The Essential Learnings are the response to a problem identified by teachers, students and parents: the curriculum overload. An "obese" curriculum prevents consolidation of what you learn, does not leave space for the development of more complex competences, does not free up space for inclusion of all students. We therefore asked teacher societies to cooperate with the Ministry to a double job: to identify the core curriculum that cannot be left behind, and to make explicit links and identification of strategies for the link between the different subjects and The Student Profile.

So, going back to the question: these documents cannot be implemented without intentionality when you teach language. If language awareness is a tool for better communication, participation, critical thinking, you must direct the activities for these goals. And obviously, you cannot do this without knowledge. Let me just give you one short example. When one studies adverbs and modality, you can just label and memorize categories or you can use the understanding of the properties of these adverbs in the identification of texts as faithful news or fake news. You then develop grammar, reading skills and critical thinking.

IS: Mother tongue classes are open to multiple genres and discourses. Over the last decades, the genres most emphasised at school involve explanation and argumentation. But this has not always been the view of mother tongue teaching. Do you find that Portuguese textbooks have, in general, broken away from the perspective of language structure-centred teaching and take into consideration that plurality of genres and discourses? 
JC: I do not really like to focus any assessment of what happens in schools on the basis of what textbooks prescribe. In general, they tend to reflect the curriculum, but the types of activities are very limited and do not really explore the whole potential of students and knowledge. So, I'm more concerned with teacher professional development than with textbooks as means to boost the quality of language learning. Textbooks are one tool among many resources that can and must be used in the classroom. Children bring with them their innate knowledge of language: much richer than any textbook. Centering the discussing of curriculum on textbooks is poor.

IMD: I would not be so optimistic about it... Most of the textbooks I have consulted do not reflect the plurality of genres and discourses in use in society and do not make the most of them. Textbooks and, presumably, the classes of most teachers predominantly use literary-type narratives. We can understand why this happens, as this is the means through which children and teenagers have quick access to reading and pleasure, but the distribution of textual genres could be (and should be) more balanced, so as not to trivialise the literary genre. Some students like reading informative texts and not all of them become readers just because they read stories and novels. Furthermore, from what I've seen, many textbooks include grammar questions that only take into account the level of knowledge and the identification of word classes and sub-classes, or of syntax rules, but they do not provide for linguistic transformations nor for the relation between grammatical items and the reading and construction of texts/discourses. What often happens is that we look for the information given by the text, but do not try to understand how the text gives that information, what linguistic-discursive mechanisms are used, and, furthermore, we take a "cold" approach to grammar, that is, we assess students on their knowledge, whether they are able to classify words and identify syntax rules. However, there is hardly any work done on the language itself, like manipulating it, changing elements and seeing the resulting changes in meaning, for example.

IS: Some mother tongue teaching-learning mindsets assume that knowledge about a language must be acquired through verbal uses, in an instrumental view of grammatical knowledge. Do you find that this relation is obvious and easy to achieve/implement in the teaching practice?

JC: I think you mean communicative approaches. That obviously depends on what aspects of grammar you consider. Language awareness implies reflection, systematic observation of data, the ability to form paradigms and patterns. Usage can be chaotic, because we do not speak or 
write in an organized manner (fortunately). Thus, exposure by itself does not guarantee effective learning. Likewise, grammar teaching without application is sterile. So, we need balanced approaches to language teaching and learning, since those radically advocating grammar-only, literature-only, communication-only will necessary fail.

IMD: I believe that using the language alone is not enough to know about it. While it is important to use the language (you can only learn to swim by swimming, to skate by skating, to write by writing, etc.), it is also important to transfer knowledge and think about the language itself. In this respect, I defend the close relationship between the grammar workshop method, as proposed by Inês Duarte, and the reading, analysis and writing of texts/discourses, as taught by Fernanda Irene and Joaquim Fonseca. This relationship was proposed by two colleagues from my university (Sónia Rodrigues and Purificação Silvano) in a text published in 2010, which is mandatory reading for my students.

IS: Grammar teaching and learning have been singled out as the problem areas in teachinglearning in compulsory education (e.g., Costa, 2008), raising discussions on the teaching methodologies thereof. Would you care to comment on this statement? What could be the reason for these difficulties felt by students?

IMD: When João Costa wrote that text, he clearly identified several factors that explained the flaws found in the students' knowledge of grammar on entering higher education. In some cases, things have already changed, for instance, national exams now include the assessment of grammar knowledge. Perhaps there is too much focus on trying to get students to acquire lots of knowledge rather than insisting on what they could do with it. If that knowledge is not put back into reading, into producing texts (written and oral), it becomes barren and apparently useless. When the teacher combines an active and even entertaining methodology with sound knowledge to address and work on grammar, students enjoy learning and do it more effectively.

JC: The biggest problem in Portugal is not the contemplation of grammar in the curriculum. It has always been there, with more or less weight or impact. The problem is the taxonomic obsession, which destroys the effectiveness of teaching. When grammar is used for language awareness, for decisions in reading, writing, speaking and comprehending, students will learn. Otherwise, it is just a pile of items you memorize and forget soon. I am not advocating that school should only teach useful and immediately applicable knowledge. Knowing about things 
is good by itself. But for me to know, I have to understand, and shallow labeling tasks do not promote deep learning.

IS: The previous questions take us to the topic of teacher training, in particular, in areas intersecting linguistics and didactics. As a teacher in teacher training courses, I'm sure you are aware of this reality. What changes have there been in the study plans of these courses in Portugal in recent years to adapt them to an European level as a result of Portugal's participation in the European Higher Education Area (1999) through the Bologna Process? How was the process conducted and what advantages and/or disadvantages did it bring to mother tongue teacher training? Do these changes in the training of teachers meet the needs of language teachers?

JC: We have some very good researchers in didactics of language in Portugal. I do not know many countries where linguists have had such a great contribution in the definition of language education policies. These researchers also teach prospective teachers. But the initial teacher preparation is never sufficient, if the teacher is not a lifelong learner.

IMD: The Bologna process brought with it the Masters degrees in Teaching, which I feel are an appropriate degree for those studying to become teachers. These degrees strengthen the training in areas of teaching and the acquisition of knowledge and skills in specific pedagogical areas and in the so-called General Educational Training area. Moreover, their aim is to raise the students' awareness and lead them to reflect more deeply on the issues at hand, hoping that they will become teachers-researchers. In the case of the Faculty of Arts and Humanities of the University of Porto, and in particular the Masters in the Teaching of Portuguese, I would like to highlight 3 aspects that correspond to this aspiration: the subjects called Portuguese Grammar Workshop (Oficina de Gramática da Língua Portuguesa), as well as other subjects focusing on Literature and Portuguese Culture, Teaching Portuguese as a Second or Foreign Language (Didática do Português Língua Não Materna), along with 2 semesters of Portuguese Teaching Methodology (Didática do Português), as our schools have today many non-native Portuguese students, and, for example, Educational Research (Investigação Educational). In some of those subjects, students are involved in small action-research projects as early as in the 1st year, so that they can experiment with solutions and analyse the outcomes of their experiences and proposals. 
IS: As a university teacher, you develop/have developed and participate/have participated in national and international projects for the development of mother tongue teaching in Portugal. How has that research in linguistics, in particular its underlying school contributed to the development of mother tongue teaching?

IMD: Pragmatics and Discourse Analysis have drawn attention to the need to study a language at the level of its use and not just the system at an abstract level. One of the contributions of the area is to show that, as Óscar Lopes once said, we rarely speak "using a subject, a predicate and well-recognised circumstances". We cannot understand a language as a system if we separate it from the conditions in which it is used. Using out-of-context grammar examples in class fabricated by the teacher does not help relate grammar knowledge with communication skills that we wish to develop in students. Another contribution of this area is the study of informal texts, because if we want to show the difference between the varying degrees of formality, by transforming discourses according to the required degree of formality, we need sound linguistic descriptions. On the other hand, the school today takes into consideration many issues of discursive appropriateness, precisely due to the advances of Pragmatics, for example. As for Discourse Analysis, it promotes the understanding of the relationship between the text and its context, allowing discursive genres to be approached in a more integrating manner.

JC: My main focus of research is theoretical syntax and language acquisition. Over 50 years of research in generative grammar yielded massive advances in the knowledge of how language works, how language develops, how language is parsed, and what happens in contexts of language impairment. Suppose you want to be a medical doctor, but you do not know details about how the body works, the structure of the patients, the development of diseases. You will not manage to perform adequately. It is the same with teaching a language. If you do not have a good understanding of the details of language, you will never be a good language teacher. How can you teach punctuation if you do not know grammatical functions? By intuition and without systematization? How can you teach language ignoring the stage of linguistic development of the child in front of you? How can you teach how to write if you ignore the relations between sounds and graphemes? The list could go on forever. The idea that, by the mere contact with texts, you develop language skills is flawed. 
IS: In Portugal, what does research in mother tongue didactics and teaching methodology mean? Do you think research is done more in some fields of mother tongue teaching methodology than in others? What are the main concerns today in research in Portugal as regards mother tongue teaching? What research needs in language teaching are specific to the Portuguese context?

IMD: There is research in didactics and teaching methodology that is closer to research in Linguistics (or in Educational Linguistics), while other branches of research are more focused on other areas, such as, for example, Literature or various teaching methods. There is some research in acquisition, for example. However, in my opinion, I feel that it should be linked to the search of solutions to the students' learning problems. One of the obvious concerns in language didactics and teaching methodologies is to relate the advances made in the linguistic description of some items with the implications that those advances will have on improving the skills of students. Knowing more in order to teach better. There's still a lot to be done. For example, understanding how to learn better. We know that a child that has been exposed to books and raised in an environment in which standard Portuguese is the spoken language will have a greater chance of being successful at school. However, research in didactics must give us clues on how to teach Portuguese language better, and more effectively, to all children, compensating those who have fewer opportunities.

JC: In general, not only in Portugal, my feeling is that we do not have enough research on educational linguistics. In many cases, it is not sufficiently grounded on linguistic evidence, in other cases, it ignores the actual contexts of schooling, which as a consequence transforms the classroom in a mini-lab, and promotes activities that are not feasible for teachers. We need to know more about the relation between language development and language teaching. About what is learnt without stimulus and what requires explicit learning. About fields that have not yet been explored like semantic development, pragmatic development, since they are critical in contexts of use. In my opinion, this research requires a close link with schools and teachers, so that effectiveness and feasibility are encompassed.

IS: There is no question that the advances in research in didactics in the professional development of teachers are important. How has this research reflected on the teaching practice? How 
is this knowledge shared with teachers and what are its effects on the curriculum of teacher training courses? How do you see teachers' performance in relation to the research carried out?

JC: We have good experiences in Portugal. One decade ago, Portugal invested on a big program of teacher training, in a program called PNEP (Programa Nacional para o Ensino do Português) [National Program for the Teaching of Portuguese]. This program involved teacher education institutes, schools, teachers, productions of resources, and it induced changes in training and in practices.

Also, the work carried out by our National Literacy Plan and by the School Libraries has been a tool for improvement in practices.

IMD: Perhaps the results of research in Didactics are not brought to the attention of future teachers. Obviously, during initial and continuous teacher training (especially if the latter is in the form of a workshop), future teachers will have knowledge of the outcomes of this research via the trainer or suggested readings. But we could do so much more. Maybe even organise the dissemination of those results in teacher training sessions, in newsletters, to drive new experiments and research work. Partnerships between those who conduct work in the field and Higher Education - university and polytechnic education - between researchers and teachers at schools, or the research work done by the latter would help teachers and, consequently, their students, profit more from the research outcomes.

IS: One final question to wrap up this long exchange of ideas: could you give three arguments that would motivate a young person to choose a career as a mother tongue teacher in Portugal?

\section{IMD:}

1. Equipping children and young people with the capacity to engage with their mother tongue is an excellent challenge for a university student pursuing a career. Every citizen should have access to the power given by the appropriate use of the language, and being part of the effort to make that happen is exhilarating.

2. Working with the Portuguese language on a daily basis is a privilege: "Última flor do Lácio, inculta e bela" [The last flower of Latium, rustic and beautiful-free translation of the first line of the poem by Olavo Bilac]. It's like being a musician and being in contact with music all the time. 
3. Being a Portuguese teacher teaches us more about the language every single day. It gives us more lexicon, more linguistic alternatives to say what we want, more knowledge about the language and literature, and how to speak or write. In other words, choosing a professional career as a Portuguese language teacher means that we constantly improve our own relationship with the language, a language that shapes us and makes us its subjects.

JC: A young person is motivated to become a language teacher if he believes in the transformative power of education as a tool for human development, if he knows that language awareness is a fundamental tool for active citizenship, and if he has a true curiosity about language and is willing to study it forever.

\section{References}

Costa, J. (2008). Conhecimento gramatical à saída do ensino secundário: estado actual e consequências na relação com leitura, escrita e oralidade. In C. Reis (Ed.), Actas do congresso internacional sobre o ensino do Português (pp. 149-165). Lisboa: Ministério da Educação-Direção-Geral da Inovação e Desenvolvimento Curricular.

Duarte, I. (1992). Oficina gramatical: contextos de uso obrigatório de conjuntivo. In M. R. Delgado-Martins, D. Pereira, A. I. Mata, M. A. Costa, L. Prista, \& I. Duarte, Para a didáctica do Português. Seis estudos de linguística (pp. 165-177). Lisboa: Edições Colibri.

Fonseca, F. I., \& Fonseca, J. (1977/1990). Pragmática linguística e ensino do Português. Coimbra: Almedina.

Fonseca, J. (1988-89). Ensino da língua materna como pedagogia dos discursos. Diacrítica, 34, 63-77. Braga: Universidade do Minho.

Ministério da Educação (1991). Plano de organização do ensino-aprendizagem, $2 .{ }^{\circ}$ Ciclo Ensino Básico. Lisboa: Imprensa Nacional Casa da Moeda.

Ministério da Educação (2009). Programas de Português para o ensino básico. Lisboa: DGIDC-ME.

Ministério da Educação (2015). Programas e metas curriculares de Português. Lisboa: DGEME.

Ministério da Educação (2018). Aprendizagens essenciais - Português. Lisboa: DGE-ME.

Silvano, P., \& Rodrigues, S. V. (2010). A Pedagogia dos Discursos e o Laboratório Gramatical no ensino da gramática. Uma proposta de articulação. In A. M. Brito (Ed.), Gramática: 
História, teorias, aplicações. Porto: Fundação Universidade do Porto - Faculdade de Letras. 275-286.

Sim-Sim, I., Duarte, I., \& Ferraz, M. J. (1997). A língua materna na educação básica - competências nucleares e níveis de desempenho. Lisboa: Ministério da Educação-Departamento do Ensino Básico.

\section{Author's information}

Isabel Sebastião is a post-doc researcher in linguistics and language teaching at University of Porto, Portugal. She is a researcher of the Centre of Linguistics of the University of Porto (CLUP) and develops research on the learning of writing/text production and Portuguese textbooks, under the supervision of Isabel Margarida Duarte, University of Porto. She obtained her PhD in 2013 (Nova University of Lisbon), with the thesis Interactivity between practice and learning discursive-textual structures in compulsory schooling - Epistolary Discourse. She authored academic papers and chapters, and oral presentations in many different academic contexts. She taught at the Higher Education and Communication College of the Polytechnic Institute of the University of Algarve and at the University Lumière Lyon 2, France.

Email: isabel.sebastiao@hotmail.com

To cite this article:

Sebastião, I. (2019). Mother language teaching in Portugal. An interview with João Costa and Isabel Margarida Duarte. Bellaterra Journal of Teaching \& Learning Language \& Literature 12(2), 108-119. DOI: https://doi.org/10.5565/rev/jt13.813 